\title{
TOWARDS AN EU STRATEGIC CULTURE: THE CHALLENGE OF RECONCILING NATIONAL CHARACTERS AND A COMMON EU SECURITY AND DEFENSE POLICY IN THE BLACK SEA
}

\author{
Olga R. CHIRIAC, \\ Associated Researcher, Center for Strategic Studies, \\ National University of Political Studies and Public Administration, Bucharest, Romania. \\ E-mail: olga.r.chiriac@gmail.com
}

\begin{abstract}
In the current global context of great power competition and while fighting to overcome and recover from the COVID-19 pandemic, the EU has embarked on the ambitious undertaking to redefine itself as a more capable, credible, independent when necessary, defence stakeholder, the EU strategic autonomy process. Throughout this endeavour, it is becoming more and more apparent that one of the more challenging dimensions of the EU strategic autonomy debate is dial of national characters and strategic cultures within the union. The aim of the paper is conceptualizing the strategic culture framework in EU context and to identify both positive and negative factors that carry the potential to influence the formation of an authentic European strategic culture. The final conclusions will assess whether any subsequent actionable policy is in fact possible in the foreseeable future, mainly to what extent an autonomous European strategic culture could act as either a facilitator or inhibitor of EU security and defence decision making.
\end{abstract}

Keywords: Black Sea; European Union; strategic autonomy; strategic culture.

\section{Introduction}

The concept of strategic culture appears more and more in the field of strategic studies. It is especially the case for the European Union (EU) ever since the union embarked on the strategic autonomy process. Talk about a more self-sufficient EU in the field of defence is nothing new, however, in the most recent years it became a decade priority. The principal aim of the article is to conceptualise the strategic cultural framework in EU context, how or if strategic culture impacts strategy and the strategic choices made in Brussels, in particular. The conclusions should be able to differentiate whether the concept acts as facilitator or inhibitor at the political-decisional level in Brussels as it relates to a common EU security and defence policy in the Black Sea. The paper is not looking to conduct an all-encompassing analysis of the concept of strategic culture by investigating the theoretical explanatory powers of the term: does it possess the capability to explain at least to some extent the relationship between strategy and national inclinations for security and defence behaviour, or is it for the most part nothing more than another intellectual justification for security and defence policy choices. Such an endeavour would be beyond the limited scope of the paper.

The paper is structured as follows: first a brief discussion around the chronology of the concept in international relations literature, second a concise presentation of the EU strategic environment, finally, the case study brings the findings down to an important strategic space in the EU security and defence architecture - the Black Sea. The paper emphasizes the role of perceptions and national strategic cultures by underlining the difference in EU security and defence posture in the Black Sea by focusing on the evolution of EU political initiatives in the 
region. Finally, we are talking about the North Atlantic Treaty Organisation's (NATO) Eastern Flank in an analysis about EU strategic thinking because, at this point in time, although the EU has developed into a regional political-economic institution with military ambitions, the alliance remains the de facto defence provider for the European Union in its entirety.

\section{Strategic Culture - A Framework for Analysis}

In spite of a truly vast amount of literature covering the topic, there is no relative academic consensus as to the ontological dimension of strategic culture. Each attempt to a definition either adds another layer or expands already convened on taxonomy.

Strategic culture was first coined by Jack Snyder and defined as "the sum total of ideas, conditioned emotional responses, and patterns of habitual behaviour that members of a national strategic community have acquired through instruction or imitation and share with each other" (Snyder 1977, 8). Nevertheless, the origins can be traced back to the "national character studies" of the 1940s and 1950s. These "represented some of the first social scientific efforts to draw connections between culture and state behaviour based largely on anthropological models." (Lantis 2005, 1). National character studies postulated that the core of a nation, the nation's character, stems from a nation's language, religious beliefs, customs, socialization patterns, as well as the interpretation of common memories (Elkins\&Simeon 1979, 127-12). One significant element of the Snyder definition is the strategic culture aspect and it warrants the inquiry into whether the European Union has succeeded in forming one or if it remains at the aspirational level. Ken Booth defined strategic culture as "a nation's traditions, values, attitudes, patterns of behaviour, habits, symbols, achievements and particular ways of adapting to the environment and solving problems with respect to the threat and use of force" (Booth 1990, 121). Values, beliefs, attitudes make their way into the definition, behaviour remaining a constant. Stephen Rosen characterized strategic culture as a concept which incorporates "beliefs and assumptions" which in turn have an impact on "choices about international military behaviour, particularly those concerning decisions to go to war, preferences for offensive, expansionist or defensive modes of warfare, and levels of wartime casualties that would be acceptable." (Rosen 2019, 12). The general agreement is that strategic culture references the behavioural choices by states as they relate to the threat or use of force. In this sense, states are strategic actors. Another general agreement is that the concept of strategic culture stems from the concept of political culture. (Gray 1984, 27). Analysing through the lens of strategic culture means to assert that changes in the interaction system are not addressed objectively but rather through the "perpetual lens provided by the strategic culture." (Gray 1984, 27). The evidence used in constructing the concept includes both words and actions, "declaratory material" such as leadership speeches and declarations and military doctrinal documents or military and political activity. Colin Gray labelled the resulting political activity and policy as strategic behaviour, or" behaviour relevant to the threat or use of force for political purposes." (Gray 1999, 50). Naturally, strategic culture and national character are not fixed concepts. They transform and are fully dynamic. More recently, there have been frequent calls for a EU "strategic concept" (van Staden et al., 2000; Biscop, 2002; Fiott, 2020), "which would set out the EU's objectives in the field of security and defence as well as a strategy of how to achieve them." (Meyer 2004, 2). In the academic debate, strategic culture is employed in foreign policy analysis in order to explain the behaviour in security and defence of either states and/or international organization. In the context of the paper strategic culture is a framework for analysis for the European Union Common Security and Defence Policy and as a measure of how the EU is looking to define itself as a strategic actor: does strategic culture act as a variable which facilitates or inhibits the development of an authentic, autonomous common security and defence policy. Is there real progress in developing an EU strategic culture? 
STRATEGIES XXI International Scientific Conference

The Complex and Dynamic Nature of the Security Environment

The strategic culture conversation in EU context makes even more sense when tied into the evolution of European security and defence policy planning and execution. The Saint-Malo declaration in 1998 marked the birth of the European Security and Defence Policy (ESDP). A few years later, the European Union Military Committee (EUMC) was set up within the EU Council (EU Council Decision of 22 January 2001) and in 2003, the EU formalized the common European Security Strategy, a policy document looking to develop an EU strategic culture "which fosters early, rapid, and earn necessary, robust intervention" (EU 2003, 11). In 2009, the Lisbon Treaty offered the opportunity for even greater cooperation on multilateral responses through a Common Defence and Security Policy (CSDP) framework. It is the European Council through unanimous decision who identifies strategic interests and objectives of the EU. The CSDP has "greatly evolved since the entry into force of the Treaty of Lisbon, both politically and institutionally" (EU Parliament, 2021). The ultimate goal is to achieve a "policy setting the EU's framework in the field of defence and crisis management, including defence cooperation and coordination between Member States" (EU Parliament, 2016). CSDP and the ESDP both drew the outlines for the European Union as a security actor and this translates into a union of joint security interest and the ways to protect them. Notably, cooperation in security and defence and integration of security and defence structures are two very different concepts.

Strategic culture in the context of the present article is convened upon as playing a role in the deeper understanding of "motivations, self-image and behaviour patterns of decisionmakers", it "helps shape" but "does not determine how an actor interacts with others in the security field" (Booth 2005, 25). Specifically, national strategic cultures do exist, however, we need to analyse whether they have a positive or negative effect towards the development and progression of an EU strategic culture.

To sum up, strategic cultural analysis has certainly gained traction in the international relations field of research. Pioneered by Lack Snyder in the late 70's, at the high of the Cold War, strategic culture has started out mostly as a concept meant to build explanatory theories for soviet strategic behaviour, especially in the nuclear realm. In time, the concept was rediscovered and extended to all other actors in the international system. Concurrently, the definition of security widened and the strategic environment became far more complex, especially due to globalization and the significant progress made in technology innovation. For the purpose of the article, the concept of strategic culture will be employed as a tool to explain state behaviour and an attempt will be made to reconcile it with the union of states which is the EU.

\section{EU, the Strategic Actor}

The strategic environment the EU is operating in has changed dramatically in the last decades, in the post-Cold War era. In the field of security and defence, national characters and national strategic cultures did not carry much traction during the Cold War. Strategic cultures developed organically at the national level, however, the world was ordered in a bipolar manner, and major strategic decisions were reached depending on the elegance of each state to either the East or the West, the USSR or the USA, the two superpowers. Present day EU is a conglomerate of 27 Member States, the union is one building block in a multipolar international system, where since the December 2017 US National Security Strategy great powers are officially back to systemic competition. While one political and economic block, in the field of defence, the union has fallen short of reaching a unitary position. Although the international system has changed, becoming far more interconnected and complex, each Member State remained heir to distinct national perspectives rooted in history, geography, culture, and geopolitics. 
There is no genuine shared perception of threats in the EU yet, no authentic consensus as too what makes the union vulnerable security wise. The EU Strategic Compass currently underway in Brussels is meant to map out a clearer direction as well as spell out the threats the union is facing. The EU remains an emerging strategic actor in the realm of security and defence not a fully formed one. It remains to be seen what the Compass will lead to as far as actionable policy. Recent reports about the Strategic Compass draft say that the EU is considering the formation of a joint military force of up to 5,000 troops by 2025 to intervene in a range of crises and without relying on the United States (US News, 2021). This is indeed very good news, nevertheless, it will hopefully not suffer the same fate as the battlegroups. In 2007 with "the introduction of the Battlegroup concept, the Union formed a (further) military instrument for early and rapid responses when necessary." (EU Council, 2013) The concept reached full operational capability on January 2007, full operationalization and application lagged. Notwithstanding, as of right now, while at the declaratory level the member states agree on the imperative of developing a more autonomous EU in security and defence, and while the EU institutions work on setting up the necessary institutional framework, the means to reach such a goal, the reality on the ground remains fragmented. Different geographical areas have different strategic interests and security is often still ensured by bilateral strategic partnerships, and, as stated before, NATO. For example, on the Eastern border of the EU, Poland and Romania rely heavily on their strategic partnership with the US as well NATO. Strategic culture is correlated to political culture and political culture is rooted in the historical memory of each nation. This is a substantial roadblock in establishing a common EU strategic culture. According to the present framework for analysis, political leadership of a state and the political elites are the decision makers when it comes to policy and strategic direction. They are the ones shaping narratives, public discourse and this in turn influences that way states behave as strategic actors. In order to form a total strategic actor, the EU needs to meet both requirements: agree on the political ends and construct the necessary means to reach those ends. The later part could in fact constitute a major advantage for the EU on the world stage because the union is a wealthy institution with substantial economic means. The European Defence Fund (EDF) is the best example of said power. Unfortunately, the bottleneck remains at the political level, where the consensus is not there. A major step in reaching a consensus was indeed the initiation of the EU Strategic Compass, the two-year process, led by the European External Action Service under the responsibility of the EU high Representative for Foreign Affairs and Security Policy (EU External Action Service, 2020). In addition to mitigating the fact that the EU lacks a common strategic culture, the compass is intended to morph into a "new security policy document" and it "must be based on a broad political consensus and a strong political will to act." (EU German Presidency Website, 2020). The Strategic Compass will address different, inter-linked areas: crisis management missions, resilience, capabilities and instruments, working with partners. A target adoption date is March 2022, under the French Presidency. It remains to be seen if the target date will be met and if indeed the compass will produce progress.

Practically, a very recent example of the EU as strategic actor is the evolution of the allied withdrawal from Afghanistan. The North Atlantic Treaty Organization (NATO)-led International Security Assistance Force (ISAF) in Afghanistan was established by the United Nations in 2001. (NATO, 2021) The declared main purpose was to train the Afghan forces as well as to assist in rebuilding government institutions. This NATO led mission included armed forces from several EU nations and, based on the premise of common historical experiences, would have been the perfect opportunity for the different states to start building a common strategic answer, a shared way of viewing military missions, their purpose. In August 2021, during the hasty western withdrawal from Afghanistan, the common EU strategic response simply did not exist. Mary Kaldor wrote about the missed opportunity to build an EU response in a moment of crisis: "A European force that remained even as the Americans left could have 
STRATEGIES XXI International Scientific Conference

The Complex and Dynamic Nature of the Security Environment

provided a powerful psychological boost to Afghan forces - and such an operation should have been well within European capabilities." (Kaldor, 2021) One option would have been to keep EU forces on the ground, however, the political will, the EU consensus was just not there. An EU strategic culture has remained an ambiguous concept, which different meanings for different groups. This is just a very recent example. Of course, it would be reductive to evaluate the EU potential to morph into a truly strategic actor by just one occurrence, nevertheless, it provides a good insight to the situation at present. The current migrant crisis at the Poland Belarus border is another opportunity, so far, it looks like Poland considers invoking NATO Article 4, no clear expression of support from Brussels. According to the Polish News Agency, European Council President Charles Michel said that the EU together with Member States and the European Commission will consider measures that are "significant and tangible" in impact(PAP,2021) One such measure is apparently funding infrastructure of the EU's eater border. Physical structure on the borders in order to protect the bloc is not a strategic answer. The root cause of the threat is not addressed.

To conclude, the EU is an emerging strategic actor, however, it has a way to go before reaching synergy. The good news is that the right steps at the political level are being taken, the more realistic news is that in spite of several security documents and political initiatives, the on the ground reality tells a different tale. Perhaps Berger's view that strategic culture is best understood as a "negotiated reality" among foreign policy elites is most fitting to describe the present phase in EU's pursuit of a common strategic culture.

\section{EU Strategic Presence in the Black Sea Region}

Barry Buzan and Ole Wæver concluded "Most threats travel more easily over short distances than over long ones" (Buzan \& Wæver 1998, p. 4). The Black Sea and the place the region occupies in EU strategic output is a fitting illustration for this assertion. The union's strategic approach towards the Black Sea Region reflects in how initiatives have materialized or not in the past.

As a theatre of naval operations, the Black Sea represents one of the maritime borders of NATO's Eastern Flank. Access to the Black Sea is limited by narrow straits, mainly the Bosphorus and the Dardanelles. The straits are on opposite ends of the Sea of Marmara. From a maritime regime stand point, the straits as well as the Sea of Marmara are part of the sovereign maritime territory of Turkey and therefore subject to the regime of internal waters. The navigational regime regulating maritime traffic in and out of the Black Sea is the Montreux Convention of 1936. The Black Sea is a semi enclosed body of water bordered by six coastal states: Bulgaria, Romania, Ukraine, Russia, Georgia and Turkey. Three of them, Bulgaria, Romania and Turkey, are NATO member, while two of them, Georgia and Ukraine, aspire to NATO accession. Finally, Bulgaria and Romania are EU members. The annexation of the Crimean Peninsula by the Russian Federation in 2014 effectively enabled Russia's expansion of its exclusive economic zones (EEZs) and the building of the Kerch Strait Bridge in 2018 which complicated the geopolitical landscape even more.

The EU strategic approach in the Black Sea is inherently linked to the very way the EU was constructed. A political and economic union first and foremost, it took a very long time as well as substantial structural changes in the international system for her to start having serious defence related conversations, especially relating to the Black Sea. Up to the present, the strategic initiatives of the union in the BSR are largely not correlated to actionable security and defence.

Black Sea Synergy (BSS) is the main EU initiative for the region. The official launch of the initiative took place February 14, 2008, in Kiev, on the occasion of a meeting of the 
ministers of foreign affairs of the EU Member States and the states in the region covered by the BSS: Armenia, Azerbaijan, Georgia, the Republic of Moldova, the Russian Federation, Turkey, and Ukraine. (MAE, 2021). BSS was launched particularly because of the strategic position of the Black Sea, "its potential in the fields of energy, transport, trade, environment, democracy building" (MAE, 2021). The declaratory interest was there, however, there lacked political follow up and there was not too much project level application.

Previously too BSS, the European Union (EU) has developed in 2003 a new working foreign policy instrument called the European Neighbourhood Policy (ENP) in order "to achieve the closest possible political association and the greatest possible degree of economic integration" with its Southern and Eastern neighbours (EU Commission, 2021). Out of the ENP came another EU political framework, the Eastern Partnership (EaP) "which Romania views as a powerful soft power instrument to anchor Eastern neighbours to EU's identity and values" (Aurescu, 2011). The Eastern Partnership was launched in 2009 and is a joint initiative involving the EU, its Member States and six Eastern European Partners: Armenia, Azerbaijan, Belarus, Georgia, the Republic of Moldova and Ukraine. This initiative is indeed a strategic move on behalf of the EU, establishing areas of "strategic interest": Azerbaijan is rich in energy resources for example, a strategic priority for the union. On the other hand, the same initiative underscores fundamental strategic divergence among EU Member States: while Poland for instance would naturally be very interested in the EU actively supporting Belarus or Ukraine in building sound democratic systems of governance, other Member States might not share in this sense of urgency. The current migrant crisis at the polish Belarusian border is an illustration of why the EU should care. Another good example is the Republic of Moldova: while Romania is vested in Moldova's European integration, other fellow EU Member States might not consider this a strategic priority. The formation of both BSS and Eastern Partnership is indicative as to the direction in which the EU was envisioning its strategic play in the Black Sea. Both put an accent on cooperation, mainly in items at the top of EU agenda such as human rights, democracy and consolidation of democratic institutions, the economy and trade, good governance, energy, transport, climate policy, maritime policy, fisheries, human security and migration.

The European Neighbourhood Policy was intended to "to create a ring of friends around the borders of the new enlarged EU" (Ferrero-Waldner, 2004). Notwithstanding commendable goals, the EU strategic actor did not manage to properly assess the threat environment, to this day, miscalculating its policy towards the Russian Federation. The Black Sea has therefore suffered from a security and defence vantage point, the EU does not have a common approach to Black Sea security and defence aspect. Black Sea security, in spite of the geopolitical significance, is still exclusively a matter for NATO and the riparian states. EU strategic culture in the Black Sea does not have any sort of power. In both Baltic and Black Seas, the Russian Federation is the regional military power. Although NATO faces the same strategic competitor in both bodies of water, the regional threat perception is very different. If the Black Sea is characterized by tension and relative mistrust, in the Baltic, the stance is very divided. The former Baltic Republics for instance, Latvia, Estonia and Lithuania, together with Poland perceive the Kremlin as a realistic and grave threat to their national security. At the opposite end of the spectrum we have Germany, who in spite of numerous declarations condemning different forms of alleged Russian aggression, have partnered up with Russia to construct Nord Stream 2, a controversial pipeline project, feared by many states in the EU and NATO to be a strategic Trojan horse. The German answer to the concerns over Nord Stream 2 was not a European answer, individual national character has trumped the overarching EU security interest.

The Three Seas Initiative (3SI) is the most recent attempt to settle the EU into its role as strategic actor. 3SI is a" politically inspired, commercially driven platform for improving 
STRATEGIES XXI International Scientific Conference

The Complex and Dynamic Nature of the Security Environment

connections among twelve EU Member States located between the Baltic, Adriatic and Black Seas" (2seas.eu, 2021). While focused on economic cooperation, in the wider context of energy and maritime security, the 3SI could very well be employed as a powerful tool in addressing EU security. It remains to be seen how this opportunity will be leveraged, not only by the participating countries, which have a strong commitment to security and defence as common denominator, but in the EU overall.

The EU strategic autonomy process, currently underway in Brussels, could be a wonderful opportunity to indeed streamline a cohesive, common strategic culture. The need for an autonomous EU is evident, it would be the needed complementarily to NATO and the immediate area of action is the EU neighbourhood. Frozen conflicts in Azerbaijan (NagornoKarabakh), Georgia (Abkhazia and South Ossetia), the Republic of Moldova (Transnistria) and Ukraine (Donetsk and Lugansk) are still looking for a political solution. They contribute to instability in the region, inherently threatening EU security.

The starting point of the present work was the question: does the emerging EU strategic culture act as a facilitator or inhibitor for a common EU security and defence policy? In concrete terms is the EU as strategic actor in the Black Sea? Through a strategic culture lens, the answer is negative, as well as multi-layered. The strategic cultures of different actors in the Baltic as well as the Black Seas act as inhibitors towards building a common EU strategic culture, however, in different ways. If in the Baltic Sea, there is essentially no need for a more assertive EU policy because the regional power, the Russian Federation does not perceive the EU and NATO as threats, in the Black Sea, the environment is far more complex and tense. In the Black Sea, Russian strategic thinking presents a posture build around the conviction that it is better to prevent a loss than to expect a positive outcome. While the efforts to create the ripe environment for the development of a cohesive EU strategic culture is a noteworthy one, it must be said that in order for this process to be relevant, it needs to be backed by more political will, to be more situation minded and regionally/geographically specific, and, finally, to be accelerated. In line with the latter, in his writings about strategic culture, Colin Gray was alerting to the fact that "Restrictive understanding of the strategic culture of others can be very dangerous for international peace and security". (Gray 1984, 26) It is in the interest of both the EU and NATO, for the European Union to continue the discussion and to pursue initiatives such as the EU Strategic Compass. Caveat, the compass will be rooted in threat assessments and intelligence sharing, not political national agendas, motivated by national strategic cultures. Being strategic means that the political decision makers build a long term blueprint for the EU in the defence realm, so far, the proposition has been at best short to medium term. The leaked draft of the compass mentions a target date of 2025 and this is nowhere near long term. The bigger picture of climate change, energy security, strategic rivalry with other great powers, all these aspects would need to be projected not the future and strategically addressed.

\section{Conclusions}

A truly common EU strategic culture would indeed facilitate common EU responses to regional threats as well as challenges in EU areas of interest or global threats such as climate change, terrorism, piracy, humanitarian crises, pandemics or proliferation of weapons of mass destruction. The paper set out to establish whether the concept acts as facilitator or inhibitor at the political-decisional level in Brussels as it relates to a common EU security and defence policy. It is clear the union is in the process of actively pursuing this goal and it is therefore important to analyse whether the union possess the capability to explain at least to some extent the relationship between strategy and defence behaviour, to define strategic interests with commonality or if, for the most part, it represents nothing more than another 
intellectual/political justification for security and defence policy choices, mostly national ones. After a review of the way the concept has been conceptualized in specialty literature and after a brief incorporation of the concept within the EU strategic landscape, the discussion outlined how the goal of EU strategic culture is still at best emergent at worst and inhibitor of common EU security and defence policy, particularly in the Black Sea. Domestic values and norms still outweigh a unifying "EU character". The main reasons behind this unevenness is the varying levels of threat perception among EU Member States, in our case, exemplified by the way different state actors perceive the Russian Federation in the Black Sea and beyond. Political initiatives in the Black Sea have existed, however, the implication of the union as a whole was minimal at best. Nevertheless, the EU does not lack the necessary means to build capabilities, it just did not manage, at least so far, to build actionable consensus around the end goal of approaching threats to EU security in a unitarian manner.

In the overarching global context of renewed great power competition between the Russian Federation, China and the USA, it will become more and more evident that the EU will at some point operationalize the goal of a common strategic culture and autonomy.

\section{BIBLIOGRAPHY:}

AURESCU, Bogdan. 2011. "The Role of the European Union in The Wider Black Sea region", Turkish Policy Quarterly, Vol.10, Number 1.

BISCOP, Sven. 2002. "In Search of a Strategic Concept for the ESDP", European Foreign Affairs Review, 7.

BUZAN, B., WAEVER, O., DeWILDE, J. 1998. Security a new framework for analysis. Lynne Rienner.

BOOTH K. 1990. The Concept of Strategic Culture Affirmed. In: Jacobsen C.G. (eds) Strategic Power: USA/USSR. Palgrave Macmillan, London. URL: https://doi.org/10.1007/978-1349-20574-5_8

Journal of the European Union. 2016. Consolidated Version of the Treaty of the European Union. Official URL: https://eur-lex.europa.eu/legal-content/EN/TXT/PDF/?uri= CELEX:12016M/TXT\&from=EN

ECKSTEIN, Harry. 1998. "A Culturalist Theory of Political Change," American Political Science Review 82.

ELKINS D.J., Simeon R.E.B. 2000. A Cause in Search of Its Effect, or What Does Political Culture Explain?. In: Crothers L., Lockhart C. (eds) Culture and Politics. Palgrave Macmillan, New York. URL: https://doi.org/10.1007/978-1-349-62397-6_2

EMMOTT, Robin. 2021. "EU to Aim for Rapid Deployment Force Without U.S. Assets by 2025, Document Says." US News, November 15, 2021. URL: https://www.usnews.com/news/world/articles/2021-11-15/eu-to-aim-for-rapiddeployment-force-without-us-assets-by-2025-document-says

European Council of the European Union, "Implementation Plan on Security and Defence". 2016. URL: https://eeas.europa.eu/sites/default/files/eugs_implementation_plan_ st14392.en16_0.pdf

European Council of the European Union. 2017. "Council conclusions on progress in implementing the EU Global Strategy in the area of Security and Defense", URL: https://www.consilium.europa.eu/en/press/press-releases/2017/03/06/conclusionssecurity-defence/ 
STRATEGIES XXI International Scientific Conference

The Complex and Dynamic Nature of the Security Environment

EU External Action Service. 2013. Common Security and Defence Policy.EU Battlegroups. URL: https://www.consilium.europa.eu/uedocs/cms_data/docs/pressdata/en/esdp/ 91624.pdf

EU External Action Service. (2016). "Shared Vision, Common Action: A Stronger Europe A Global Strategy for the European Union's Foreign And Security Policy.", URL: https://eeas.europa.eu/archives/docs/top_stories/pdf/eugs_review_web.pdf

EU External Action Service. 2016. "The Common Security and Defence Policy (CSDP)”, URL: https://eeas.europa.eu/topics/common-security-and-defence-policy-csdp/5392/commonsecurity-and-defence-policy-csdp-structure-instruments-agencies_en

Dr. FERRERO-WALDNER, Benita. 2004. "Commissioner for External Relations and European Neighborhood Policy Speaking note, Press Conference to launch first seven Action Plans under the European Neighbourhood Policy. URL: https://ec.europa.eu/ commission/presscorner/detail/en/SPEECH_04_529

Franco-British Declaration on European Defence. 4 December 1998. Saint-Malo.

FREEDMAN, Lawrence. 2004. "Can the EU develop an effective military doctrine?", in Steven Everts, Lawrence Freedman, Charles Grant, François Heisbourg, Daniel Keohane and Michael O'Hanlon (eds), A European Way of War, Centre for European Reform, London.

GILPIN, Robert G. 1996. "No One Loves a Political Realist", in Benjamin Frankel (ed.), Realism: Restatements and Renewal, Special Issue of Security Studies, Vol. 5, No. 3, London: Frank Cass.

GOLDSTEIN, Judith and Robert KEOHANE (eds). 1993. "Ideas and Foreign Policy: Beliefs, Institutions, and Political Change", Ithaca, NY: Cornell University Press.

GRAY, Colin S. 1984. "Comparative Strategic Culture”, The US Army War College Quarterly: Parameters 14. URL: https://press.armywarcollege.edu/parameters/vol14/iss1/13

GRAY, Colin S. 1999. "Modern Strategy", New York: Oxford University Press.

HOWORTH, Jolyon and John T.S. Keeler (eds.). 2003. "Defending Europe: The EU, NATO and the Quest for European Autonomy" (New York/Basingstoke: Palgrave Macmillan.

HOWORTH, Jolyon. 2019. "Strategic Autonomy and EU-NATO Cooperation: A Win-Win Approach", L'Europe en Formation, vol. no 389, no. 2.

JOHNSTON, Alastair. 1995. "Thinking About Strategic Culture”, International Security, Vol. 19, No. 4.

JOHNSTON, Alastair. 1999. "Strategic Culture revisited: a reply to Colin Gray", Review of International Studies, Vol. 25, No. 3.

KALDOR, Mary. 2021. Autonomous in Afghanistan: How the Europeans could have stayed after US withdrawal, ECFR Council, September 13, 2021. URL: https://ecfr.eu/article/ autonomous-in-afghanistan-how-the-europeans-could-have-stayed-after-us-withdrawal/

KATZENSTEIN, Peter J. 1996. "Cultural Norms and National Security: Police and Military in Postwar Japan”, Ithaca and London: Cornell University Press.

KATZENSTEIN, Peter J.(ed.). 1996. "The Culture of National Security: Norms and Identity in World Politics", New York: Columbia University Press.

KATZENSTEIN, Peter J. 1996. "Introduction", in Peter J. Katzenstein (ed.), The Culture of National Security: Norms and Identity in World Politics, New York: Columbia University Press. 
LANTIS, Jeffrey S. 2005. "American Strategic Culture and Transatlantic Security Ties," in Kerry Longhurst and Marcin Zaborowski, eds., Old Europe, New Europe and the Transatlantic Security Agenda.

LANTIS, Jeffrey S. 2009. Strategic Culture: From Clausewitz to Constructivism. In: Johnson J.L., Kartchner K.M., Larsen J.A. (eds) Strategic Culture and Weapons of Mass Destruction. Initiatives in Strategic Studies: Issues and Policies. Palgrave Macmillan, New York. URL: https://doi.org/10.1057/9780230618305_3

MAE. "Black Sea Synergy". 2021. URL: https://www.mae.ro/en/node/52664

MEYER, Christoph O. 2004. "Theorising European Strategic Culture: Between Convergence and the Persistence of National Diversity," Centre for European Policy Studies, CEPS Working Document No.204.

MOGHERINI, Federica, 2015. "The European Union in a Changing Global Environment. A More Connected, Contested and Complex World". Brussels, EEAS.

Polish Press Agency. 2021. Migration Crisis Aims to destabilize EU=Polish PM. November 10, 2021. URL: https://www.pap.pl/en/news/news\%2C996554\%2Cmigration-crisisaims-destabilise-eu-polish-pm.html

ROSEN, Stephen Peter. 1991. "Winning the Next War", Ithaca NY, Cornell University Press,

ROSEN, Stephen Peter. 1996. Societies and Military POWER: India and Its Armies, Ithaca NY, Cornell University Press,

SNYDER, Jack. 1977. "The Soviet Strategic Culture: Implications for Limited Nuclear Operations", RAND Corporation, Santa Monica, CA, R-2154-AF

VAN STADEN, Alfred, KEES Homan, KREEMERS, Bert, PIJPERS Alfred and DE WIJK, Rob. 2000. "Towards a European Strategic Concept", Netherlands Institute of International Relations 'Clingendael', The Hague. 